УДК 336.64

DOI: https://doi.org/10.37320/2415-3583/14.9

Крейдич I.M.

доктор економічних наук, професор, Наиіональний технічний університет Украйни «Київський політехнічний інститут імені Ігоря Сікорського» ORCID: https://orcid.org/0000-0002-4594-2160

Товмасян B.P.

кандидат економічних наук, докторант, ПВНЗ «Свропейський університет» ORCID: https://orcid.org/ 0000-0002-1802-8939

\title{
СИСТЕМАТИЗАЦІЯ КРИТЕРІЇВ ОЦІНЮВАННЯ ФІНАНСОВОЇ ПОЛІТИКИ АВІАЦІЙНИХ ПІДПРИЕМСТВ
}

У статті досліджено науково-методичні підходи до систематизачії критерї̈в оцінювання фінансової політики авіаційних підприємств. Визначено, щз відслідковування, регулювання та оптимізація використання ресурсного потенціалу, активів, контроль за рівнем віддачі капіталу, інвестованих коштів, збалансування власних та залучених фінансових ресурсів є неможливими без відповідної методики оцінювання результатів операційної, інвестиційної та фінансової діяльності підприємств. Обтрунтовано, що об'єктивною основою забезпечення ефективного функціонування авіаційних підприємств мають бути розроблені критерії та система показників оиінювання фінансової політики, яка дасть змогу визначати її стан та коригувати подальші дї, модернізуючи системоутворюючі елементи управлінського та економічного впливу на фінансові процеси розвитку підприємства. Запропоновано критерії очінювання фінансової політики підприємства, представлено систему показників оиінювання ефективності та напрямів фінансової політики підприємства.

Ключові слова: фінансова політика підприємства, фінанси, фінансово-економічні відносини, фінансовий менеджмент, критерії оиінювання фінансової політики, фінансові показники.

Постановка проблеми. Метою діяльності підприємства є досягнення прибутковості, яка дасть змогу як розвиватись, так і продовжувати функціонувати у перспективі. Залежність такої мети від ефективно реалізованої фінансової політики є очевидною. Підприємствам необхідно регулярно відслідковувати, регулювати та оптимізувати використання ресурсного потенціалу, активів, слідкувати за рівнем віддачі капіталу, інвестованих коштів, балансувати власні та залучені фінансові ресурси, тому актуальним науковим завданням є розвиток наукових положень із систематизації критеріїв оцінювання фінансової політики авіаційних підприємств.

Аналіз останніх досліджень і публікацій. Питанням аналізу та оцінювання фінансового стану підприємств, ефективності фінансової діяльності суб'єктів виробничо-економічної діяльності присвячено наукові праці багатьох вітчизняних та зарубіжних учених. Варто відзначити роботи таких науковців, як І.Ф. Стефанів [1], К.А. Пріб, Н.І. Патика [7], А.В. Василенко [5], І.Г. Ловінська [3]. Вченими запропоновано методику оцінювання фінансової стійкості організацій, підходи до діагностики в системі управління підприємствами та показники оцінювання ефективності інших напрямів діяльності виробничо-економічних систем. Водночас залишається таким, що потребує подальшого розвитку, питання формування системи показників ефективності та напрямів фінансової політики авіаційних підприємств на основі критеріїв спрямованості модернізації такої політики.

Мета статті. 3 огляду на вищевикладене та відсутність уніфікованої системи показників оцінювання ефективності фінансової політики авіаційних підприємств у вітчизняній економічній науці в умовах, коли забезпечення безперервної діяльності авіаційних під- приємств є пріоритетним завданням державної економічної політики сталого розвитку, вважаємо за доцільне дослідити та обгрунтувати комплексну систему показників ефективності фінансової політики авіаційних підприємств.

Виклад основного матеріалу. Фінансова політика має містити чітко визначений список цілей та методів їх досягнення, перелік джерел фінансування поточних та капітальних витрат, сформовану методику оптимізації процесів формування та використання матеріальних і фінансових ресурсів, обгрунтовані критерії дієвості механізмів реалізації планів компанії, функціональні методи контролю за ефективністю реалізації окреслених цілей, критерії оцінювання досягнутих результатів [1, с. 543]. Саме тому для авіаційних підприємств мають бути розроблені критерії та система показників оцінювання фінансової політики, яка дасть змогу визначати іiї стан та коригувати подальші дії, модернізуючи системоутворюючі елементи управлінського та економічного впливу на фінансові процеси розвитку підприємства.

Фінансова політика авіаційних підприємств має оцінюватись у розрізі критеріїв оборотності, маневреності, іммобілізації та приросту, що формує збалансовану управлінську систему модернізації авіаційних підприємств, забезпечуючи ключові ознаки прояву іiі ефективності, а саме динамічну фінансову стійкість, відтворюваність фінансових ресурсів, гнучкість власних вкладень, достатність фінансових ресурсів на незаплановані витрати (рис. 1).

У формуванні чотирьох зазначених напрямів ми керувались критеріями спрямованості модернізації фінансової політики авіаційних підприємств, зазначеними нижче. 


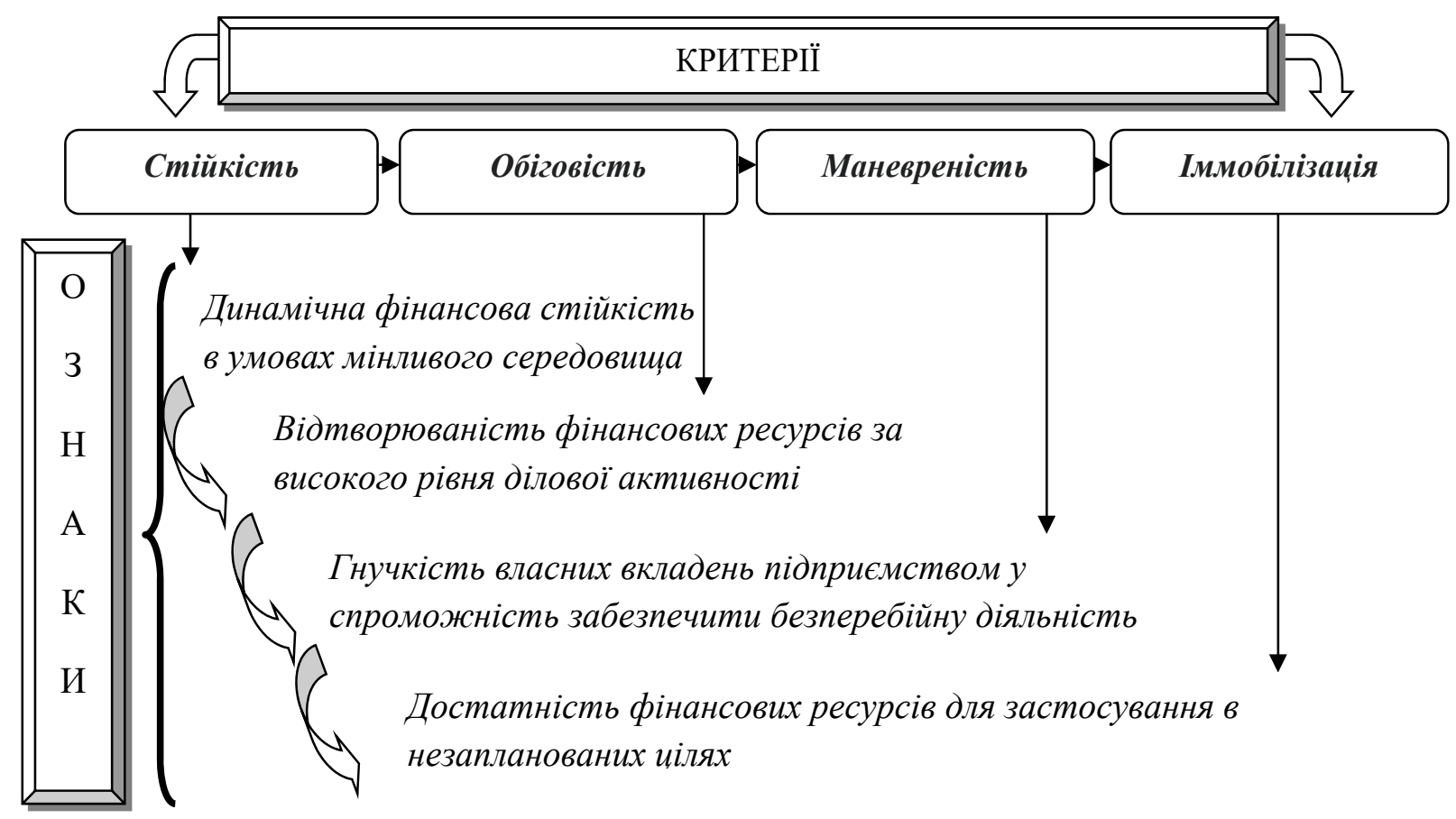

Рисунок 1 - Критерії оцінювання фінансової політики підприсмства

Джерело: розроблено авторами

1.Стійкість. Критерій стійкості характеризуватиме підприємство з позиції стабільного фінансового стану, економічно самостійних дій та можливості подальшого розвитку. Ефективна фінансова політика підприємства має забезпечити його фінансово-стійкий стан та спроможність подальшого фінансування діяльності. У дослідженнях науковців фінансова стійкість є позитивним показником як діяльності, так і розвитку підприємства. Такої думки дотримуються O.M. Зайцев, I.I. Приймак, визначаючи іiі станом, за якого зберігається здатність стабільного прогресивного розвитку [2, с. 23], спроможністю функціонувати впродовж тривалого періоду, одержуючи достатній для стабільного розвитку прибуток, забезпечуючи економічно обгрунтоване співвідношення джерел фінансування та активів і збалансоване надходження й виплату грошових коштів [3, с. 98] за негативних подій та мінливих впливів зовнішнього середовища. Крім того, фінансова стійкість характеризує внутрішній потенціал підприємства 3 позиції ефективного застосування ресурсів. Як відзначають Н.В Алєксеєнко, А.В. Василенко, це є станом стан матеріальних, економічних i трудових ресурсів підприємства, їх розподілом та використанням, які забезпечують розвиток підприємства на основі зростання прибутку й капіталу за збереження платоспроможності та кредитоспроможності в умовах допустимого рівня ризиків [4, с. 56-65], працездатним станом щодо досягнення запланованих результатів за наявності різних мінливих впливів [5, с. 39]. Отже, з позиції фінансової політики такий критерій визначатиме динамічну фінансову стійкість підприємства в умовах мінливого середовища.

2. Оборотність. Вибір цієї зони ефективності фінансової політики визначається класичною необхідністю iï реалізації як інструменту забезпечення інтенсивності циклічного використання різних ресурсів фінансової сфери підприємства, що дає йому змогу функціонувати, нарощуючи потенціал. Коефіцієнти оборотності, як відомо, належать до системи оцінювання ділової активності, проте з позиції фінансової політики вони $\epsilon$ зручним інструментом визначення іiї ефективності як отриманий фінансовий результат від вкладень у різні активи. Як зазначає С.В. Іонін, відтворювальний характер господарської діяльності, що спрямована на одержання прибутку, як передумови та визначальної бази щодо максимізації ринкової вартості бізнесу чи підприємства (цілісного майнового комплексу), підвищує значущість управління оборотністю усіх видів активів [6, с. 193]. Отже, завдяки критерію оборотності доцільно визначати відтворювальний ефект, отриманий завдяки результативним заходам фінансової політики.

3. Маневреність. Під терміном «маневреність підприємства» розуміють здатність підприємства розмістити засоби, залучені з різних джерел фінансування, в активах підприємства у такий спосіб, який максимально забезпечуватиме його фінансову стійкість, стабільність та ефективну виробничо-господарську діяльність [7]. Цей критерій $з$ позиції фінансової політики визначає обсяг фінансових ресурсів, який підприємство спроможне спрямовувати на різні види діяльності, використовуючи як інструмент інвестування, антикризових заходів чи регулювання потоків. На основі маневреності можна визначити ефективність фінансової політики 3 позиції вкладень в активи, оборотного капіталу тощо. Для характеристики результативності фінансової політики маневреність визначатиме гнучкість власних вкладень підприємством у діяльність, його спроможність забезпечити безперебійну діяльність. 
4. Іммобілізація. Критерій іммобілізації дасть змогу розкривати стан фінансової політики підприємства 3 точки зору його привабливості контрагентів у реалізації фінансових операцій, забезпечення поточних зобов'язань фінансовими ресурсами, можливість за потреби вилучати кошти на різні потреби. Для характеристики фінансової політики критерій іммобілізації дасть можливість виявити достатність фінансових ресурсів для застосування в інших передбачуваних або непередбачуваних цілях.

Кожна із зазначених ознак ефективності фінансової політики має оцінюватись на основі відповідних об'єктів, на які націлена така політика. Отже, доречно їх деталізовано визначити. На наш погляд, фінансова політика підприємства в контексті їі ефективності має бути націлена на дві ключові паралелі, першою 3 яких $є$ регулювання обігу засобів з подальшим зростанням фінансових ресурсів, а другою - витрачання фінансових ресурсів на необоротні активи для спроможності отримувати досконалішу систему засобів, функціонування яких перетворюватиметься на дохід. Отже, об’єктами фінансової політики підприємства у такому разі має бути подвійний комплекс: управління власними капіталом, інвестиціями та позиковим капіталом; управління необоротними активами, а саме основними засобами та нематеріальними активами.

Спрямованість фінансової політики на активи підприємства виражається у їх довгостроковому та короткостроковому залученні, відтворенні, контролюванні та регулюванні для утворення стійкої фінансово-економічної системи діяльності та розвитку підприємства.

Здебільшого фінансова політика щодо необоротних активів передбачає фінансове стратегування, пов'язане 3 амортизаційними відрахуваннями для поновлення потенціалу основних засобів, залучення нематеріальних активів, а також довгострокові інвестиції. 3 огляду на досліджуваний аспект напрямів модернізації фінансової політики, що характеризується активними діями на короткострокову та середньострокову перспективи, як об'єкт політики варто розглядати оборотні активи. З урахуванням того, що фінансова політика є елементом фінансового управління підприємством, варто зазначити саме управлінський аспект іiї впливу на оборотні активи. Як зазначають науковці, управління оборотними активами є частиною короткострокової фінансової політики підприємства, спрямованої на вирішення найбільш важливих поточних фінансових проблем, що дає змогу поліпшити фінансовий стан підприємства та підвищити його фінансову стійкість і платоспроможність за досить короткі терміни [8, с. 573], при цьому таке управління може здійснюватися в розрізі їх видів. Отже, йдеться про управління дебіторською заборгованістю; управління грошовими коштами й поточними фінансовими інвестиціями; управління запасами [9], тобто фінансова політика щодо оборотних активів може реалізовуватись як у комплексі, так і окремо за їх видами.

За видами (за елементним складом) оборотні активи підприємства розподіляють на матеріальні запаси (сировини, товарної та готової продукції), дебіторську заборгованість підприємства, грошові кошти та їх еквіваленти тощо [10, с. 79]. Як відомо, до складу оборотних коштів входять $[11$, с. 982$]$ :
1) грошові кошти (готівка, кошти на рахунках у банках та депозити);

2) короткострокові фінансові інвестиції (високоліквідні активи, які утримуються підприємством задля збільшення прибутку (відсотків, дивідендів тощо), зростання вартості капіталу або інших вигід для інвестора та вільно конвертуються у певні суми грошових коштів і які характеризуються незначним ризиком зміни їх вартості);

3) дебіторська заборгованість (сума заборгованості юридичних та фізичних осіб, які внаслідок минулих подій заборгували підприємству певні суми грошових коштів, їх еквівалентів або інших активів на певну дату) $[11$, с. 982$]$.

Зазначимо, що об'єктами фінансової політики підприємства серед оборотних активів є запаси, дебіторська заборгованість, грошові кошти та їх еквіваленти.

Таким чином, узагальнимо систему оцінювання ефективності фінансової політики підприємства. Насамперед зазначимо, що вона має бути спрямована на розвиток стійкості, інтенсифікацію оборотності, забезпечення маневреності та дотримання ефективних умов іммобілізації. Оцінюванню мають підлягати два комплекси застосованих на підприємстві фінансових інструментів, а саме регулюючий та оптимізаційний (рис. 2).

Регулюючий комплекс інструментів призначений для врегулювання потоків та обороту за активами й капіталом, а оптимізаційний спрямований на необоротні активи для забезпечення безперебійної діяльності підприємства, оптимального розподілу фінансових ресурсів для придбання та введення в обіг основних засобів і нематеріальних активів. Такий розподіл можна підтвердити врахуванням того, що фінансова політика спрямована на два взаємопов'язаних напрями, а саме політику доходів і витрат, які на практиці реалізують відповідні функції фінансів [12]. Політика доходів і витрат є ключовою або вихідною, оскільки з їі цілей випливають цілі та заходи в розрізі кредитної, операційної, облікової, податкової, інвестиційної та ринкової політики підприємства [12]. При цьому до основних напрямів ¥іi розроблення належать розроблення облікової, управлінської, кредитної політики; управління оборотними коштами, дебіторською, кредиторською заборгованістю, витратами, вибір амортизаційної, дивідендної та інвестиційної політики, цінової політики [12]. Зазначений комплекс підтверджує відповідність визначеним об'єктам таких комплексів:

1) регулюючий комплекс: оборотні активи (запаси, грошові кошти та їх еквівалентність, дебіторська заборгованість), капітал (власний капітал, інвестиції, позиковий капітал), які спрямовані до підвищення дохідної частини фінансової політики;

2) оптимізаційний комплекс: основні засоби та нематеріальні активи, проведення фінансової політики стосовно яких зорієнтоване за забезпечувальні процеси та розподіл фінансових ресурсів щодо їх залучення, впровадження у використання, ремонту/оновлення та виведення з активів підприємства.

Висновки. За результатами проведеного дослідження узагальнено науково-методичні підходи до оцінювання ефективності фінансової політики підприємств. Визначено, що система оцінювання фінансової 


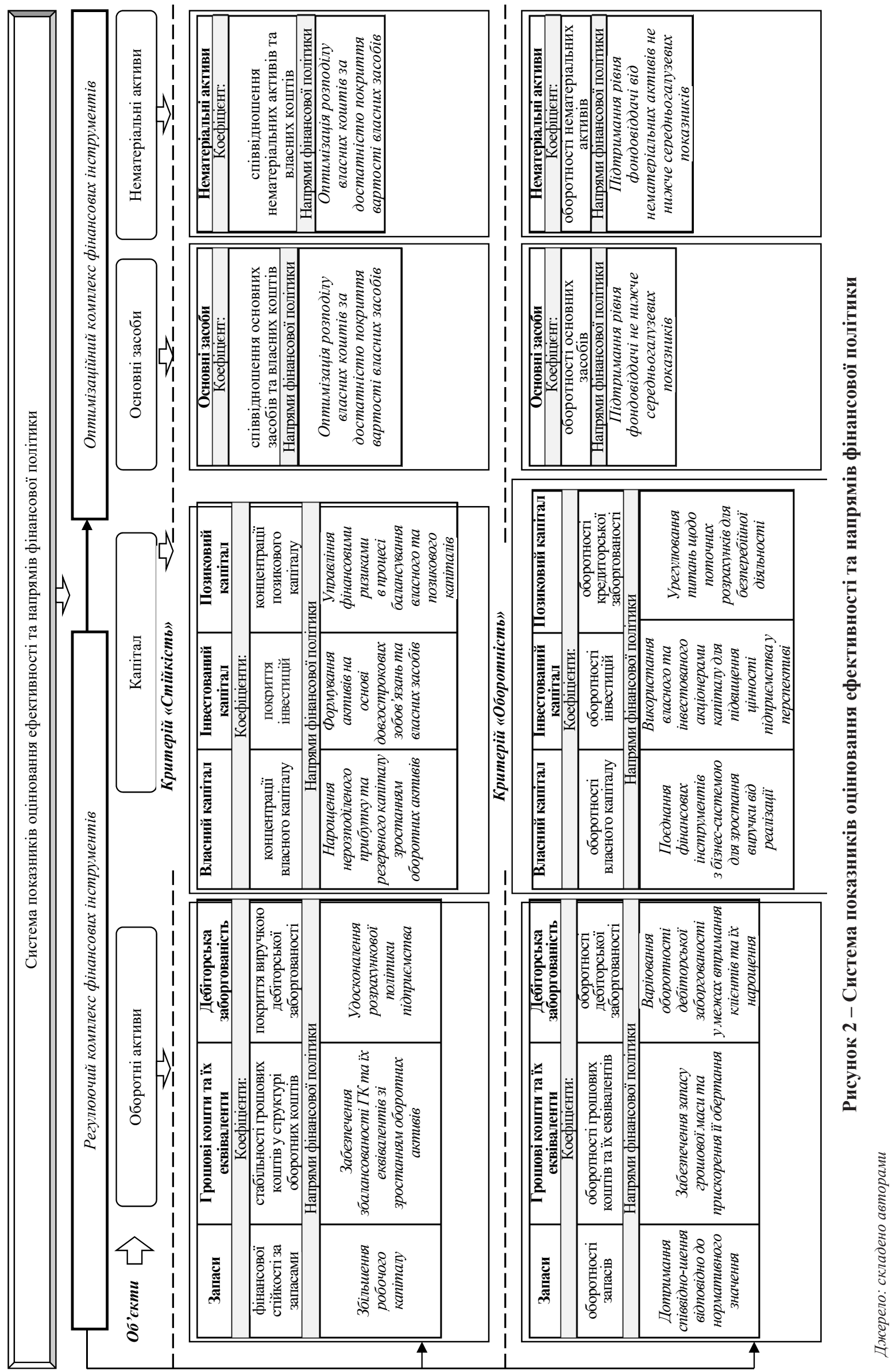




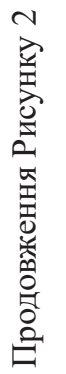

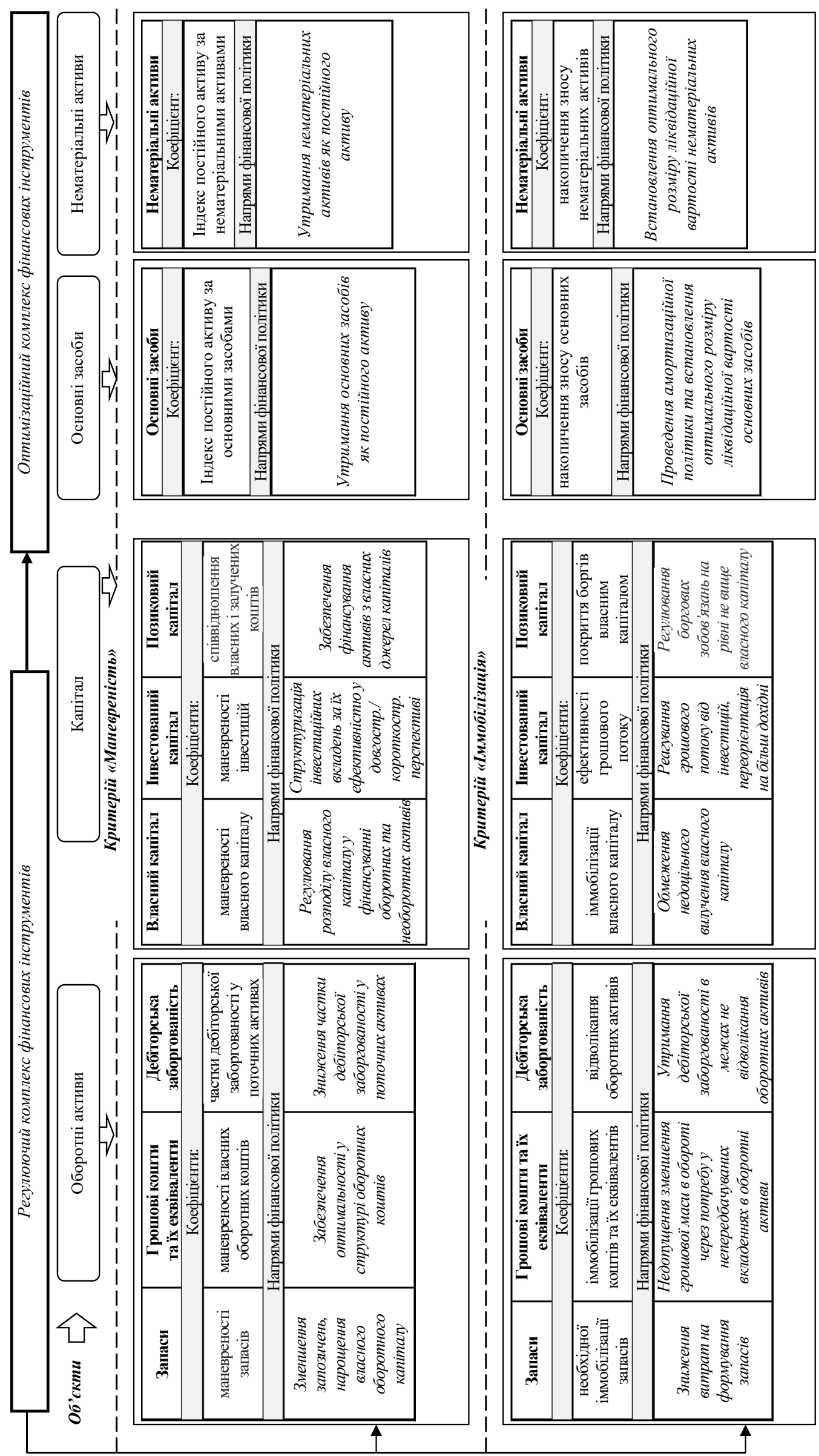


політики авіаційних підприємства має бути спрямована на два комплекси інструментів, а саме регулюючий та оптимізаційний.

Інструменти зазначених комплексів фінансових інструментів є взаємозалежними. Регулюючий комплекс відповідає за дохідну частину діяльності підприємства, а оптимізаційний - за витратну, спрямовану на його розвиток. Система показників оцінювання об'єктів фінансової політики має грунтуватись на змістовності критеріальної основи, яку складають розвиток стійкості, інтенсифікація оборотності, забезпе- чення маневреності та дотримання ефективних умов іммобілізації.

Елементом наукової новизни дослідження є розвиток наукових положень із систематизації критеріїв оцінювання фінансової політики авіаційних підприємств, спрямованого на модернізацію фінансової політики таких підприємств.

Перспективним напрямом подальших досліджень є розроблення методичного підходу до прогнозування фінансової політики авіаційних підприємств у кризовий та посткризовий періоди.

\section{Список використаних джерел:}

1. Стефанів І.Ф. Напрямки удосконалення фінансової політики підприємств. Глобальні та національні проблеми економіки. 2019. Вип. 13. С. 542-547.

2.Зайцев О.Н. Оценка экономической устойчивости промышленных предприятий (на примере промышленности строительных материалов) : автореф. дисс. ... канд. экон. наук : спец. 08.00.05 «Экономика и управление народным хозяйством». Хабаровск, 2007. 23 с.

3. Ловінська І.Г. Фінансова стійкість організацій як індикатор економічного потенціалу. Фінанси, облік $i$ ayдит. 2014. Вип. 1 (23). С. 252-259.

4. Алексеенко Н.В. Управление устойчивым развитием промышленных предприятий. Економіка і організаџія управління. 2009. Вип. 2 (6). С. 50-60.

5. Василенко А.В. Менеджмент устойчивого развития предприятий : монография. Киев : Центр учебной литературы, 2015. $648 \mathrm{c}$.

6. Іонін С.В. Оборотність активів в умовах використання методу нарахувань: аналітичний аспект. Економічний аналіз. 2008. Вип. 2 (18). С. 193-197.

7. Пріб К.А., Патика Н.І. Діагностика в системі управління. Київ : ЦУЛ, 2016. 431 с.

8. Дехтяр Н.А., Дейнека О.В., Черноус Т.М. Управління оборотними активами підприємства. Економіка $і$ суспільство. 2017. Вип. 8. С. 572-578.

9. Бодаренко О.С. Методологічні основи управління оборотними активами підприємств. Інвестиції практика та досвід. 2008. № 4. C. 40-44.

10. Донін Є.О. Особливості сучасних підходів до специфіки класифікації оборотних активів підприємства. Економіка $i$ організащія управління. 2018. № 1 (29). С. 75-85.

11. Павленко О.П., Бурсук Г.Ю. Фінансовий аналіз оборотних активів та оптимізація джерел їх формування. Молодий вчений. 2017. № 10 (50). С. 981-984.

12. Дергалюк Б.В., Парфенюк М.В. Економічна сутність поняття «фінансова політика» та принципи ії реалізації на підприємстві. Ефективна економіка. 2017. № 5. URL: http://www.economy.nayka.com.ua/?op=1\&z=5574 (дата звернення: 08.09.2020).

\section{References:}

1. Stefaniv I.F. (2019) Napriamky udoskonalennia finansovoi polityky pidpryiemstv [Directions for improving the financial policy of enterprises]. Global and national economic problems, no. 13, pp. 542-547.

2. Zaitsev O.N. (2007) Otsenka ekonomicheskoy ustoychivosti promyishlennyih predpriyatiy (na primere promyishlennosti stroitelnyih materialov) [Assessment of the economic sustainability of industrial enterprises (using the example of the building materials industry)] (PhD Thesis). Habarovsk : Pacific National University.

3. Lovins'ka I.G. (2014) Finansova stijkist' organizaciyi yak indy'kator ekonomichnogo potencialu [Financial stability of organizations as an indicator of economic potential]. Finance, accounting and auditing, vol. 1, no. 23, pp. $252-259$.

4. Alekseenko N.V.(2009) Upravlenie ustoychivyim razvitiem promyishlennyih predpriyatiy [Industrial sustainability management]. Economics and management organization, no. 2, pp. 50-60.

5. Vasilenko V.A. (2005) Menedzhment ustoychivogo razvitiya predpriyatiy [Enterprise Sustainable Development Management]. Kyiv : Center for educational literature.

6. Ionin Ye.V. (2008) Oborotnist aktyviv v umovakh vykorystannia metodu narakhuvan: analitychnyi aspect [Asset turnover in terms of accrual method: analytical aspect]. Economic analysis, vol. 2, no. 18, pp. 193-197.

7. Prib K.A. (2016) Diahnostyka v systemi upravlinnia [Diagnostics in the control system], Kyiv : Center for educational literature. (in Ukrainian)

8. Dekhtyar N.A., Deineka O.V., Chernous T.M. (2017) Upravlinnia oborotnymy aktyvamy pidpryiemstva [Management of current assets of the enterprise]. Economy and society, vol. 8, pp. 572-578.

9. Bondarenko O.S. (2008) Metodolohichni osnovy upravlinnia oborotnymy aktyvamy pidpryiemstv [Methodological bases of current assets management of enterprises]. Investments: practice and experience, vol. 4, pp. 40-44.

10. Donin Y.O. (2018) Osoblyvosti suchasnykh pidkhodiv shchodo spetsyfiky klasyfikatsii oborotnykh aktyviv pidpryiemstva [Features of modern approaches to the specifics of the classification of current assets of the enterprise]. Economics and organization of management, vol. 1, no. 29, pp. 75-85.

11. Pavlenko O.P., Bursuk H.Yu. (2017) Finansovyi analiz oborotnykh aktyviv ta optymizatsiia dzherel yikh formuvann [Financial analysis of current assets and optimization of sources of their formation]. A young scientist, vol. 10, pp. 981-984.

12. Derhaliuk B.V., Parfeniuk M.V. (2017) Ekonomichna sutnist poniattia "finansova polityka" ta pryntsypy yii realizatsii na pidpryiemstvi [The economic essence of the concept of "financial policy" and the principles of its implementation in the enterprise]. Efficient economy, vol. 5. Available at: http://www.economy.nayka.com.ua/?op=1\&z=5574 (accessed 08 September 2020). 
Kreidych Iryna

National Technical University of Ukraine "Igor Sikorsky Kyiv Polytechnic Institute"

Tovmasian Vahan

Private Higher Educational Institution "European University"

\section{CRITERIA FOR EVALUATION \\ OF THE FINANCIAL POLICY OF THE AVIATION ENTERPRISES}

The article is devoted to the scientific and methodological approaches to the systematization of the financial policy criteria of aviation enterprises. It is determined that monitoring, regulation and optimization of the usage of resources, assets, capital return control, investments, balance between own and loan financial resources are impossible without development and implementation of an appropriate complex methodology for aviation enterprises' activities evaluation. It is justified that the objective basis for ensuring of the effective functioning of aviation enterprises should be the specific criteria and a system of financial policy analysis indicators, which will allow determining its status and adjusting further actions aiming the modernization of financial management system. In the framework of the conducted study, the scientific and methodological approaches to assessing of the corporate financial policy effectiveness are developed. It is determined that the corporate financial policy evaluation system should be based on two sets of tools - regulatory (current assets and capital, which are aimed at increasing the revenue side of financial policy) and optimization (fixed assets and intangible assets, in respect of which the conducting of financial policy is focused on the supportive processes and on the allocation of financial resources for their attraction, repair/renewal and withdrawal from the assets of the enterprise). These set of tools are interdepended. The regulatory tool is responsible for the revenue of the enterprise, and the optimization tool - for the cost base. The system of financial policy analysis indicators should be based on the financial stability assurance, turnover increase, ensuring maneuverability and compliance of the assets and there immobilization. The scientific novelty of the study is the development of scientific provisions for the systematization of criteria for evaluation of the financial policy of the aviation enterprises, aimed at modernizing the financial policy of such enterprises. The promising area for further research is the development of the methodology of the aviation enterprises'financial policy forecasting during the crisis and post-crisis periods.

Key words: enterprise financial policy, finance, financial and economic relations, financial management, criteria for evaluation of financial policy, financial indicators.

JEL classification: M20, E37, L93 